\title{
IDENTIFIKASI UJI FORMALIN PADA MIE BASAH MENGUNAKAN EKSTRAK UBI JALAR UNGU (Ipomoea batatas L.) DI PASAR TRADISIONAL DESA NIRU MUARA ENIM
}

\author{
Rahmi Garmini' ${ }^{1}$, Ayu Nengria ${ }^{1}$ \\ ${ }^{1}$ Fakultas Sains dan Teknologi Kesehatan, Institut Ilmu Kesehatan dan Teknologi \\ Muhammadiyah Palembang \\ email: rahmi.garmini@gmail.com
}

\begin{abstract}
The use of chemical additives, especially formaldehyde in food, needs to be watched out for together, both by producers and consumers. The use of formaldehyde in food is not allowed because it can cause poisoning in the human body. The purpose of this study was to describe the use of anthocyanin extract of purple sweet potato (Ipomoea batatas L.) as a natural indicator for formalin detection. The method used is experimental design. The results of this study can be seen that purple sweet potato contains anthocyanins which can be an indicator material for formalin which is acidic, this can be seen from the change in the color of the anthocyanin extract which changes when reacted with formalin, and seen from the purple sweet potato extract it turns reddish blue.
\end{abstract}

Keywords: chemical additives, purple sweet potato, formalin, anthocyanin

\section{PENDAHULUAN}

Kebutuhan pokok yang mendasar bagi setiap manusia terdiri dari kebutuhan sandang, pangan dan papan. Pada zaman yang modern ini kebutuhan manusia semakin beragam. Hal tersebut tercermin pada tingkat kebutuhan masyarakat yang semakin beragam dan semakin meningkat, sehingga mengakibatkan masyarakat kesulitan dalam hal menentukan mana kebutuhan primer dan mana kebutuhan sekunder. Namun, dari sekian banyak kebutuhan manusia, kebutuhan pangan, sandang, dan papan masih menjadi kebutuhan pokok yang mesti selalu menempati urutan atas dalam hal permintaan kebutuhan masyarakat. ${ }^{1}$

Pangan merupakan kebutuhan manusia yang sangat mendasar karena berpengaruh terhadap eksestensi dan ketahanan hidup,baik dipandang dari segi kuantitas dan kuaitasnya. Mengingatkan dari kepentingan yang demikian tinggi, prasyaratan yang harus di penuhi dalam upaya mewujudkan sumber daya manusia yang berkualitas. ${ }^{2}$ Pangan adalah segala sesuatu yang berasal dari sumber hayati produk pertanian, perkebunan, kehutanan, perikanan, perternakan, dan air, baik yang diolah maupun tidak diolah yang diperuntukkan sebagai makanan atau minuman bagi konsumsi manusia, termasuk bahan tambahan pangan, bahan baku pangan, dan bahan lainnya yang digunakan dalam proses penyiapan, pengolahan, dan/atau pembuatan makanan atau minuman. ${ }^{3}$

Mie merupakan produk makanan yang terbuat dari tepung terigu. Mie banyak di gemari oleh masyarakat dari anak-anak sampai orang dewasa karena memiliki cita rasa enak selian itu praktis dalam mengolahnya dan harganya relatif murah. Ada macam- macam jenis mie, tapi secara umum mie di bedakan menjadi dua yaitu mie kering dan mie basah. ${ }^{4}$

Mie basah yaitu mie mentah yang mengalamin perebusan air mendidih sebelum di pasarkan, mie ini memiliki kadar airnya sekitar 52\%. Mie basah tidak bisa disimpan terlalu lama. Pembuatan dan penanganan 
yang baik membuat mie tersebut bertahan selama 36 jam, pada musim kemarau sedangkan pada musim penghujan mie tersbut bisa bertahan kira - kira 20 - 22 jam karna mikroflora terutama jamur atau kapang dapat tumbuh pada mie basah dengan keadaan lembab dan suhu yag tidak terlalu tinggi. Mie basah merupakanan makanan yang memiliki kadar air yang cukup tinggi (+ $60 \%$ ). Bahan - bahan yang digunakan pembuatan mie basah adalah tepung terigu , air, garam,bahan pengembang, zat pewarna, bumbu dan telur. Tepung terigu berfungsi untuk membentuk struktur mie, sumber protein dan karbohidrat, melarutkan garam dan membentuk sifat kenyal gluten. garam berperan dalam membentuk cita rasa membuatkan tekstur meningkatkan fleksibilitas dan elastisistasmie serta mengikat air. Putih telur di gunakan untuk mencegah penyerapan minyak.4 Mie instan dan mie basah sama-sama kurang menyehatkan. Keduanya mengalami proses berkali-kali, sehingga mudah diserap sekaligus meningkatkan kadar gula darah. Sudah kurang sehat, lalu bercampur dengan formalin Mi basah yang sudah tercampur formalin tampak mengkilat, bertahan lebih dari 15 hari pada suhu kamar, dan mie tidak akan lengket. ${ }^{5}$

Penggunaan bahan tambahan kimia khususnya formalin dalam pangan perlu diwaspadai bersama, baik oleh produsen maupun konsumen. Penggunaan formalin pada makanan tidak diperbolehkan karena dapat menyebabkan keracunan pada tubuh manusia. Gejala keracunan formalin yang dapat dilihat antara lain adalah: mual, sakit perut yang akut disertai muntah-muntah, diare berdarah, timbulnya depresi susunan syaraf dan gangguan peredaran darah. Formalin pada dosis rendah dapat menyebabkan sakit perut akut disertai muntah-muntah, timbulnya depresi susunan syaraf serta terganggunya peredaran darah. Pada dosis tinggi, formalin dapat menyebabkan diare berdarah, kencing darah, muntah darah dan akhirnya menyebabkan kematian. ${ }^{6}$

Formalin digunakan oleh produsen yang tidak bertangung jawab untuk pembuatan kerupuk, beras, mie, lontong (sebagai pengeras), ketupat (sebagai pengeras), bakso, kecap dan mie basah. Fungsi formalin yang sebenarnya digunakan dalam dunia industri non pangan seperti bahan untuk pengawetan mayat, sebagai desinfektan, pembersih lantai, kapal, gudang dan pakaian dan sering juga digunakan sebagai insektisida serta bahan baku pabrik-pabrik resi plastik dan bahan peledak. $^{7}$

Badan pengawas obat dan makanan (BPOM) Palembang pada tahun 2017 menemumkan setidaknya 15 makanan yang mengandung formalin yang di jualkan di pasar bedug dikota baturaja kabupaten ogan kering ulu dari 22 sampel. $^{8}$ BPOM Palembang pada tahun 2018 menemukan sejumlah makanan yang mengandung makanan yang mengandung formalin dan boraks di 12 pasar bedug di Palembang dan paling mendominasi penggunakan bahan berbahaya formalin ini pada makanan rujak mie dan tahu goreng. ${ }^{9}$

Data penelitian pada tahun 2004 oleh BPOM di Indonesia menemukan bahwa terdapat kandungan bahan kimia formalin paling banyak pada mie basah. ${ }^{10}$ Hasil penelitian sebelumnya pada sepuluh sampel mie basah menunjukkan bahwa tujuh sampel mie basah di Bogor, Jakarta dan Depok mengandung formalin. ${ }^{11}$ Hal yang sama juga dikemukakan juga oleh penelitian sebelumnya yaitu dari 20 sampel mie basah di Depok, ditemukan 11 sampel positif mengandung formalin. ${ }^{12}$ Sedangkan hasil penelitian terdahulu yang dilakukan terhadap 36 pedagang mie basah di Pasar Tradisional Kota Semarang menunjukkan bahwa $41,7 \%$ mie basah mengandung formalin dengan kadar rata-rata $795,71 \mathrm{ppm} .{ }^{13}$

Ubi jalar ungu (Ipomoea batatas L) atau biasa dikenal dengan ketela eambat dalam bahasa Inggrisnya sweet potato adalah 
sejenis tanaman budidaya. Bagian yang dimanfaatkan adalah akarnya yang membentuk umbi dengan kadar gizi (karbohidrat) yang tinggi. Di Afrika, umbi ubi jalar menjadi salah satu sumber makanan pokok yang penting. Di Asia, selain dimanfaatkan umbinya, daun muda ubi jalar juga dibuat sayuran. Terdapat pula ubi jalar yang dijadikan tanaman hias karena keindahan daunnya. ${ }^{14}$

Warna ungu pada ubi jalar disebabkan oleh adanya zat warna alami yang disebut antosianin. Antosianin adalah kelompok pigmen yang menyebabkan warna kemerahmerahan, letaknya di dalam cairan sel yang bersifat larut dalam air.$^{15}$ Komponen antosianin ubi jalar ungu adalah turunan mono atau diasetil 3-(2-glukosil)glukosil-5glukosil peonidin dan sianidin. ${ }^{16}$ Salah satu jenis flavonoid dari tumbuh-tumbuhan yang dapat berfungsi sebagai antioksidan adalah zat warna alami yang disebut antosianin. Berdasarkan penelitian sebelumnya dari hasil tentang pemanfaatan ekstrak antosianin dari bahan alam untuk identifikasi formalin pada tahu putih ditunjukan bahwa kandungan zat antosianin banyak terdapat pada stroberi, anggur, buah naga, dan ubi ungu yang mana pada penelitian ini dapat mengindetifikasi formalin pada tahu. ${ }^{17}$ Tujuan penelitian ini adalah untuk mengetahui gambaran penggunaan ekstrak antosianin ubi jalar ungu (Ipomoea batatas L.) sebagai bahan indikator alami pendeteksi formalin.

\section{METODE PENELITIAN}

\section{A. Definisi Operasional}

1. Ekstrak Ubi Jalar ungu adalah ubi ungu yang telah direbus setelah itu ditumbuk dan di tambah dengan etanol $70 \%$ kemudian di saring untuk mengambil ekstrak nya.

2. Mie Basah adalah Mie basah yang diduga mengandung formalin.

\section{B. Desain Penelitian}

Desain penelitian yang digunakan adalah eksperimen atau percobaan. Mie basah yang di dapatkan di Pasar Tradisional Desa Niru
Kabupaten Muara Enim yang diuji dengan ekstrak ubi jalar ungu, apabila mie basah tersebut berubah menjadi biru kemerahan berarti teridentifikasi formalin.

\section{Peralatan dan Cara Kerja}

\section{Alat}
a. Gelas takar/ Teko ukur
b. Timbangan
c. Cobek/ulekan/belender
d. Mangkok keramik
e. Gelas bekas aqua
f. Tisu
g. Spatula/sendok
h. Saringan
i. Pisau dan gunting

2. Bahan
a. Ubi jalar ungu
b. Mie basah
c. Etanol $70 \%$
d. Air bersih

\section{Cara Kerja}

a. Produser penelitian

Persiapan Ubi Jalar

1. Timbang ubi jalar ungu sebanyak 50gr, 100gr, 150gr dan 200 gr.

2. Kupas dan Bersihkan ubi jalar ungu.

3. Ubi jalar yang sudah di timbang dan di bersikan selanjutnya direbus dan ditumbuk/dihaluskan.

b. Persiapan pelarut

Pelarut yang di gunakan adalah etanol dengan konsentrasi sebesar $70 \%$ dengan berbeda $\mathrm{ml}$ nya yaitu $50 \mathrm{ml}, 100 \mathrm{ml}, 150 \mathrm{ml}$, dan $200 \mathrm{ml}$

c. Proses ekstraksi

Ekstraksikan ubi jalar ungu dengan variasi alkohol tersebut menggunakan metode ekstraksi maserasi untuk mendapatkan ekstrak antosianinnya. Sebanyak 50gr 100gr 150gr dan 200gr ubi jalar ungu dan $50 \mathrm{ml}$, $100 \mathrm{ml}, 150 \mathrm{ml}$,dan $200 \mathrm{ml}$ etanol 
dimasukan ke dalam gelas takar kemudian proses ekstraksi dilakukan selama $45-60$ menit sambil sesekali dilakukan pengadukan sehingga pigmen ungu pada ubi.

Setelah proses ekstraksi, saring larutan alkohol yang telah berubah warna menggunakan saring. Perubahan warna ungu pada alkohol menandakan bahwa antosianin pada ubi jalar ungu telah terekstrak dan bercampur dengan pelarut.

d. Prosedur Pengujian Sampel Mie Basah

1. Siapkan rangkaian alat yang terdiri dari pisau,mangkok keramik,sendok, ekstrak ubi jalar ungu dan sampel mie basah dengan berat $50 \mathrm{gr}, 100 \mathrm{gr}$ $150 \mathrm{gr}$ dan $200 \mathrm{gr}$.

2. Siapkan sampel Mie basah sebanyak 100 gr yang akan diuji dan air secukupnya

3. Potong kecil - kecil sampel menggunakan pisau

4. Selanjutnya pindahkan potongan sampel pada mangkok keramik dan larutkan dengan beberapa sendok air sampai membasahi sampel menggunakan sendok dan tunggu beberapa saat agar zat

Tabel 1

Nama pedagang,kode sampel jenis makanan jumlah pegulangan

\begin{tabular}{|c|c|c|c|c|}
\hline No & Inisial pedagang & Kode sampel & Jenis makanan & Pengulangan \\
\hline 1. & SS & $\mathrm{A}$ & Mie basah & A1 - A4 \\
\hline 2. & $\mathrm{EO}$ & B & Mie basah & B1 - B4 \\
\hline 3. & SI & $\mathrm{C}$ & Mie basah & $\mathrm{C} 1-\mathrm{C} 4$ \\
\hline 4. & DA & $\mathrm{D}$ & Mie basah & D1 - D4 \\
\hline & otal & & & 16 \\
\hline
\end{tabular}

Sumber : Data primer

Dari tabel 1. diatas didapatkan jumlah pengulangan sebanyak 16 sampel mie basah aditif yang terkandung pada makanan terlarut dalam air

5. Kemudian masukan media penguji ke mangkok keramik yang terdapat sampel uji tersebut sambil di aduk menggunakan spatula/sendok agar mempercepat media penguji bereaksi.

6. Langkah terakhir adalah menilai apakah perubahan warna yang terjadi dapat mengindentifikasikan ada atau tidaknya kandungan formalin pada sampel makanan selama 5 menit dan aduk sampel hingga tercampur dengan ekstrak tersebut.

\section{Pengolahan dan Analisis data}

Pengolahan dan analisis data dengan cara melihat dan mengamati hasil percobaan atau pengolahaan data secara deskriptif (gambaran) dengan melihat hasil dari perubahan warna pada mie basah setelah ditetesi ekstrak antosianin ubi jalar ungu. Apabila mie basah berubah warna menjadi biru kemerahan, maka mie basah dinyatakan positif mengandung formalin dan sebaliknya.

\section{HASIL DAN PEMBAHASAN}

Penelitian melakukan pengambilan sampel di 4 pedagang mie basah yang ada di pasar trasisional Desa Niru Kabupaten Muara Enim pada bulan Mei-Juni 2020. 


\section{Jurnal Delima Harapan 2021}

tradisional Desa Niru Kabupaten Muara Enim. Dari 16 sampel mie basah yang didapatkan dari pedagang mie basah di pasar tradisional Desa Niru Kabupaten Muara Enim dilakukan pengujian dan pengamatan yang dilakukan mengunakan ekstrak ubi jalar ungu dengan ekstrak yang berbeda yaitu 50 $\mathrm{ml}, 100 \mathrm{ml}, 150 \mathrm{ml}$, dan $200 \mathrm{ml}$, maka mendapatakan hasil nya sebagai berikut di tabel 2:

Tabel 2. Hasil Pengamatan

\begin{tabular}{|c|c|c|c|c|c|}
\hline \multirow[t]{2}{*}{$\begin{array}{c}\text { Inisial } \\
\text { pedaga } \\
\text { ng }\end{array}$} & \multirow[t]{2}{*}{$\begin{array}{c}\text { Pengula } \\
\text { ngan }\end{array}$} & \multirow[t]{2}{*}{$\begin{array}{c}\text { Berat mie } \\
\text { basah }\end{array}$} & \multirow[t]{2}{*}{$\begin{array}{l}\text { Konsentrasi } \\
\text { ekstrak ubi } \\
\text { ungu }\end{array}$} & \multicolumn{2}{|c|}{$\begin{array}{c}\text { Hasil Pengamatan } \\
\text { Setelah di tetesi ekstrak ubi } \\
\text { ungu }\end{array}$} \\
\hline & & & & Warna & $\begin{array}{c}\text { Positif(+) } / \\
\text { Negatif(-) }\end{array}$ \\
\hline \multirow{4}{*}{$\begin{array}{l}\text { SS } \\
\text { (A) }\end{array}$} & A1 & $100 \mathrm{gr}$ & $50 \mathrm{ml}$ & Tidak berubah & Negatif(-) \\
\hline & A2 & $100 \mathrm{gr}$ & $100 \mathrm{ml}$ & Tidak berubah & Negatif(-) \\
\hline & A3 & $100 \mathrm{gr}$ & $150 \mathrm{ml}$ & Tidak berubah & Negatif(-) \\
\hline & $\mathrm{A} 4$ & $100 \mathrm{gr}$ & $200 \mathrm{ml}$ & Tidak berubah & Negatif(-) \\
\hline \multirow{4}{*}{$\begin{array}{l}\text { EO } \\
\text { (B) }\end{array}$} & B1 & $100 \mathrm{gr}$ & $50 \mathrm{ml}$ & Berubah warna & Positif(+) \\
\hline & B2 & $100 \mathrm{gr}$ & $100 \mathrm{ml}$ & Berubah warna & Positif(+) \\
\hline & B3 & $100 \mathrm{gr}$ & $150 \mathrm{ml}$ & Berubah warna & Positif(+) \\
\hline & B4 & $100 \mathrm{gr}$ & $200 \mathrm{ml}$ & Berubah warna & Positif(+) \\
\hline \multirow{4}{*}{$\begin{array}{l}\text { SI } \\
\text { (C) }\end{array}$} & $\mathrm{C} 1$ & $100 \mathrm{gr}$ & $50 \mathrm{ml}$ & Tidak berubah & Negatif(-) \\
\hline & $\mathrm{C} 2$ & $100 \mathrm{gr}$ & $100 \mathrm{ml}$ & Tidak berubah & Negatif(-) \\
\hline & $\mathrm{C} 3$ & $100 \mathrm{gr}$ & $150 \mathrm{ml}$ & Tidak berubah & Negatif(-) \\
\hline & $\mathrm{C} 4$ & $100 \mathrm{gr}$ & $200 \mathrm{ml}$ & Tidak berubah & Negatif(-) \\
\hline \multirow{4}{*}{$\begin{array}{l}\text { DA } \\
\text { (D) }\end{array}$} & D1 & $100 \mathrm{gr}$ & $50 \mathrm{ml}$ & Tidak berubah & Negatif(-) \\
\hline & D2 & $100 \mathrm{gr}$ & $100 \mathrm{ml}$ & Tidak berubah & Negatif(-) \\
\hline & D3 & $100 \mathrm{gr}$ & $150 \mathrm{ml}$ & Tidak berubah & Negatif(-) \\
\hline & D4 & $100 \mathrm{gr}$ & $200 \mathrm{ml}$ & Tidak berubah & Negatif(-) \\
\hline
\end{tabular}

Keterangan (+)Positif,berubah warna

(-) Negatif, tidak berubah warna

Dari tabel 2. setelah dilakukan pengujian pada mie basah pada pasar tradisional dengan menguunakan ekstrak ubi jalar ungu dengan 4 kali pengulangan mendapatkan hasil bahwa 1 sampel mie basah yang terdapat pada pasar tersebut positif mengandung bahan tambahan makanan yang berupa formalin dilihat dari perubahan warna pada mie basah menjadi biru kemerah-merahan. Hal ini sama dengan peneliti sebelumnya Nuhman, Aprily Esti Wilujeng (2017) bahwa ekstrak ubi ungu bisa mengidentifikasi formalin dalam tahu putih dengan cara ditetesi pada tahu tersebut, jika terjadi perubahan warna pada sampel makanan tersebut, maka makanan tersebut tidak aman dikonsumsi oleh masyarakat karena mengandung formalin. ${ }^{17}$
Hal ini juga sama dengan penelitian dilakukan Neny Rochyani*,Muhammad Rizky Akbar,Yongki Randi tahun 2017. Dimana menunjukan bahwa hasil ekstrak ubi jalar ungu dapat dijadikan sebagai indikator alami dalam mendeteksi formalin dan boraks pada makanan. Dan pada penelitian ini mendapatkan hasil perubahan warna yang terjadi pada makanan yang di duga mengandung formalin akan berubah menjadi biru kemerah-merahan terjadi karena ekstrak ubi jalar ungu mengandung zat antosianin. Antosianin pada ubi ungu tidak kalah dengan banyak jika dibandingkan dengan tumbuhan jenis lain yaitu berkisaran 14,68 - 210 $\mathrm{mg} / 100 \mathrm{~g}$ bahan baku. Sekitar $80 \%$ dari total antosianin tersebut bentuk antosianidin yang 
banyak terkandung dalam ubi ungu adalah bentuk sianidin dan peonidin. ${ }^{18}$

Menurut Sinta Ratna Dewi tahun 2019. Menyebutkan juga bahwa zat antosianin bisa terbukti mendeteksi formalin pada beberpa sampel makanan karena zat antosianin termasuk golongan antioksidan alami. Antosianin akan berubah warna seiring dengan perubahaan nilai $\mathrm{pH}$. pada $\mathrm{pH}$ tinggi antosianin cenderung berwarna biru tua sampai kehijuan atau bisa tidak berwarna sedangkan pada $\mathrm{pH}$ rendah berwarna merah keunguan pada $\mathrm{pH}$ kurang dari 4. Dan formalin memiliki sifat asam akan menyebabkan perubahan warna merah pada makanan tersebut. ${ }^{19}$

\section{KESIMPULAN}

Berdasarkan penelitian dapat disimpulkan bahwa dari keempat sampel mie basah yang ditetesi ekstrak ubi jalar ungu terdapat 1 sampel mie basah yang berubah warna menjadi biru kemerahan yang berarti mengandung formalin, dan 3 sampel mie basah lainnya tidak mengalami perubahan warna. Diharapkan dapat menjadi media informasi bagi masyarakat tentang penggunaan ekstrak ubi jalar ungu untuk mendeteksi formalin pada makanan di rumah dengan mudah.

\section{REFERENSI}

1. Suryana, Achmad. 2001. Kebijakan Ketahanan Pangan Nasional (Online), (http://pse.litbang.deptan.go.id/ind/pdf files/Anjak_2 005_IV_15.pdf) di akses tanggal 20 Oktober 2019

2. Undang-Undang Pangan No 18 Tahun 2012 Tentang Pangan

3. Undang-Undang Nomor 7 Tahun 1996 tentang Pangan

4. Purnawijayanti. 2009. Mie sehat (cara pembuatan, resep-resep olahan dan peluang bisnis). Kanisius. Yogyakarta

5. 5.Hutabarat, P. 2010. Analisa Kandugan Formalin Pada Mie Basah Serta Ciri-ciri fisik Mie Basah Yang Mengandung Formalin dan Yang Negatif Mengandung Formalin di Pasar Tradisional Medan Tahun 2010. Skripsi. Universitas Sumatera Utara
6. 6.Suhada,Rikky. 2012 .Higiene Sanitasi Pengolahan Dan Analisa Boraks Dan Formalin Pada Bubur Ayam Yang Dijual Dikecamatan Medan Sunngal Tahun2012. Skripsi. Medan :Universitas Sumatera Utara

7. WHO. 2016. Data base keracunan makanan

8. Balai Pengawasan Obat Dan Makan (BPOM) Nasional .2005. Bahan Tambahan Ilegal Boraks, Formali, Rhodamin B Pada Makanan Mie Dan Pempek Bekerja Sama Dengan Bpom Daerah Makasar Dan Palembang Insitutut

9. Balai Pengawasan Obat Dan Makan (BPOM) .2018. Bahan Tambahan Pada Makanan Tajkil Di Daerah Palembang Sumatra Selatan.

10. BPOM RI,et al. 2004. Bahan Tambahan Ilegal- Borak, Formalin, Dan Rhodamin B dalam jurnal food watch ; Sistem Keamanan Pangan Terpadu dalam skirpsi

11. Shenna, A. 2011. Kadar formalin dan metanil yellow dalam mie basah yang beredar di pasaran secara kromatografi cair kinerja tinggi. Skripsi. Program Studi Kimia. Fakultas Matematika dan Ilmu Pengetahuan Alam Universitas Pakuan. Bogor .Dalam ejournal ; Analisis Kandungan Formalin Pada Mie Basah Pada Beberapa Lokasi Di Kota Ambon . Yusthinus T. Male, Lina I. Letsoin dan Netty A. Siahaya .Jurusan Kimia, Fakultas Matematika dan Ilmu Pengetahuan Alam, Universitas Pattimura

12. Habsah. 2012. Gambaran pengetahuan pedagang mie basah terhadap perilaku penambahan boraks dan formalin pada mie basah di kantin-kantin Universitas $X$ Depok Tahun 2012. Skripsi. Program Studi Ilmu Gizi. Fakultas Kesehatan Masyarakat. Depok

13. Ekki, I. R.U. 2013. Studi identifikasi kandungan formalin dan boraks dalam mie basah yang diperoleh dari Pasar Tradisional Kota Semarang. Skripsi. 
Fakultas Kesehatan Diponegoro. Semarang.

14. 14.Nollet, L.M.L. (1996). Handbook of Food Analysis: Physical Characterization and Nutrient Analysis. Marcell Dekker Inc, New York

15. Suda, I., Oki, T., Masuda, M., Kobayashi, M., Nishiba, Y. dan Furuta, S. (2003). Review: Physiological functionality of purplefleshed seet potatoes PPcontaining anthocyanins and th[eir utilization in foods. Japan Agricultural Research Quarterly 37: 167-173.

16. Oki, T., dkk. 2008. Involvement of Anthocyanins and Other Phenolic Compounds in Radical Scavenging Activity of Purple-Fleshed ASweet Potato Cultivars. Journal of Food Science. ; 67 (5): 1752-56
17. Nuhman, Aprily Esti Wilujeng. 2017. Pemanfaatan Ekstrak Antosianin Dari Bahan Alam Untuk Identifikasi Formalin Pada Tahu Putih. Jurnal Sains Vol.7 No.14 (2017)

18. Rochyani Neny ,Muhammad Rizki Akbar, Yongky Randi . 2017. Pembuatan Media Uji Formalin Dan Boraks Menggunakan Zat Antosianin Dengan Pelarut Etanol 70\% . Jurnal Redoks Universitas Pgri Palembang Volume 2, Nomor 1, Januari - Juni 2017

19. Dewi Sinta Ratna.2019. Identifikasi Formalin Pada Makanan Menggunakan Ekstrak Kulit Buah Naga. Jurnal Nasional Ilmu Kesehatan (Jnik) Volume 2 Edisi 1 2019 Issn: 2621-6507 